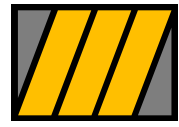

ESCUELA DE NEGOCIOS Universidad Torcuato Di Tella

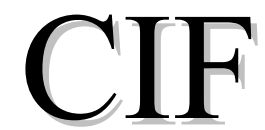

Centro de Investigación en Finanzas

Documento de Trabajo 12/2006

\title{
Optimal Debt? On the Insurance Value of International Debt Flows to Developing Countries
}

\author{
Eduardo Levy Yeyati \\ Universidad Torcuato Di Tella and IDB
}




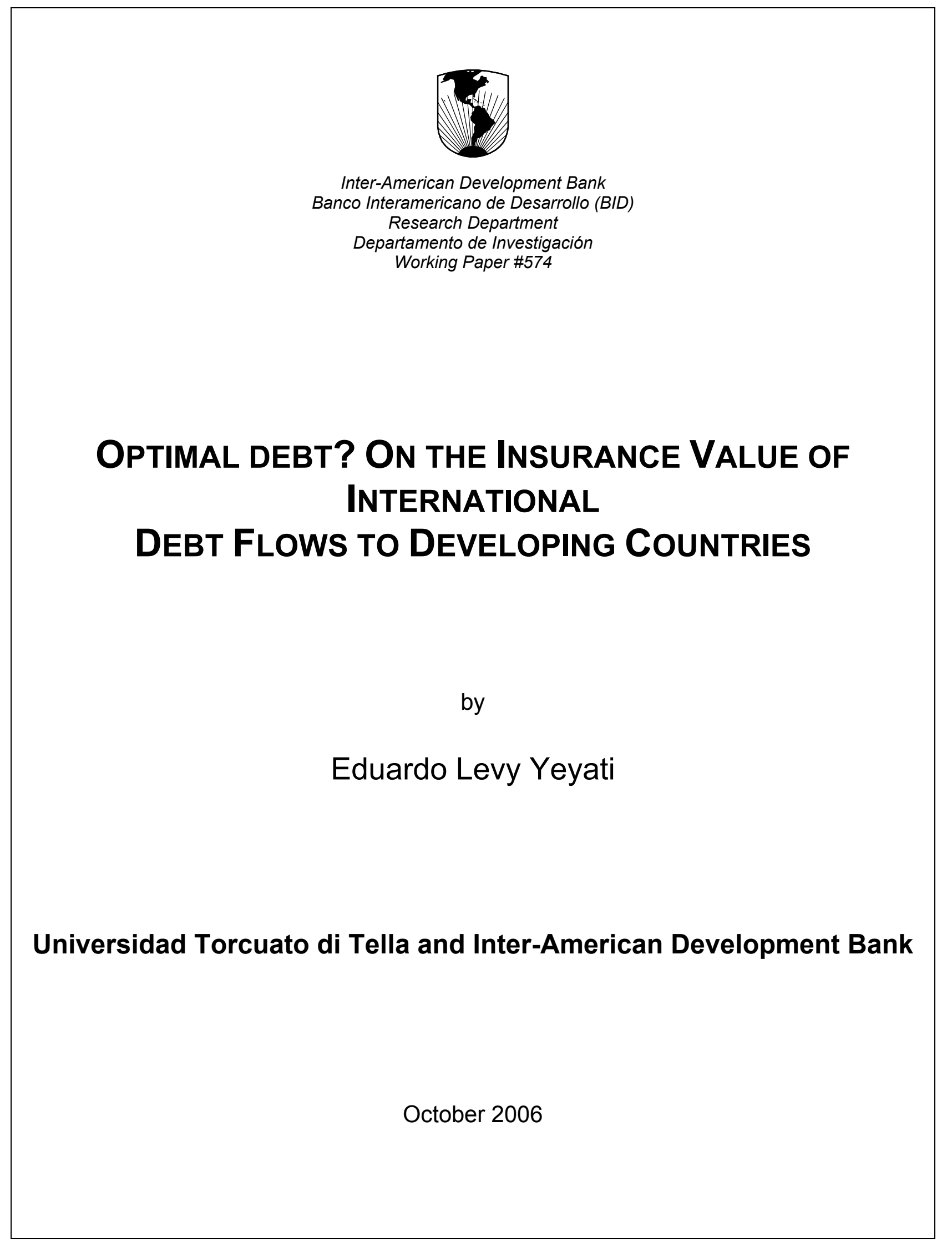


(C)2006

Inter-American Development Bank

1300 New York Avenue, N.W.

Washington, DC 20577

The views and interpretations in this document are those of the authors and should not be attributed to the Inter-American Development Bank, or to any individual acting on its behalf.

This paper may be freely reproduced provided credit is given to the Research Department, InterAmerican Development Bank.

The Research Department (RES) produces a quarterly newsletter, IDEA (Ideas for Development in the Americas), as well as working papers and books on diverse economic issues. To obtain a complete list of RES publications, and read or download them please visit our web site at: http://www.iadb.org/res. 


\begin{abstract}
$^{1}$
According to reputation models of sovereign debt, the incentives to repay are proportional to the income insurance benefits provided by access to international markets. This paper, however, documents that private net lending to developing countries exhibits a procyclical or acyclical pattern, contradicting this premise. By contrast, official debt net flows exhibit a countercyclical patter. In addition, the paper shows that (both current and past) defaults are associated with lower net debt flows. The findings, which are robust to various additional controls, cast doubt on the reputation view of sovereign debt markets. At the same time, they suggest that reputation may account for the success of the (implicit) preferred creditor status enjoyed by multilateral lenders.
\end{abstract}

${ }^{1}$ The author wishes to thank Jorge Morgenstern for excellent research assistance. 


\section{Introduction}

There is a basic disconnect between the sovereign debt literature and the reality of developing countries. In particular, the literature's main premise is that sovereign debt plays an incomesmoothing (insurance) role, and that defaults are the outcome of the strategic choice between keeping the payment and losing access to future insurance faced by the borrower in times of bonanza. In this paper, I show that both premises are at odds with the evidence.

The sovereign debt literature has centered on the question of why the sovereign repays its debt - a prerequisite for the existence of sovereign debt in the first place - and has for the most part assumed that debt is used primarily to smooth out income shocks, that is, to insure against adverse real shocks by increasing disposable income in bad states of the world, at the expense of a smaller income (due to repayment) in good states of the world. Indeed, it is precisely this insurance value that provides the sovereign's main incentive to repay according to the conventional view - and the motivation for lending to a sovereign in the absence of any sizeable collateral. According to the basic argument, a country may smooth real income shocks by subscribing a contract with an international lender whereby the country receives a positive transfer (borrows) in low-income years, and a negative transfer (repays) in high-income years. In their seminal paper, Eaton and Gersovitz (1981) showed that such a contract could be sustained solely on the basis on the country's credit record (reputation) inasmuch as the loss of insurance benefits exceeds the maximum payment under the contract.

In a well-known critique, Bulow and Rogoff (1989a) showed that the country could always use the part of the payment due to subscribe a cash-in advance insurance contract that offers the same insurance benefits as the original (defaulted) contract, an option that creates incentives to default that, in turn, would discourage lenders to lend solely on the basis of reputation. However, this critique hinged on three non-trivial hypothesis: i) the lender faces no commitment problem; ii) lenders do not collude; and iii) the saving decision of the government is time consistent. Only under these assumptions, a second lender would provide a cash-in advance insurance contract to a defaulting country, and the government would use the retained payment to insure against future shocks.

A number of papers have questioned the realism of these assumptions. Kletzer and Wright (2000) have argued that a positive level of sovereign debt can be sustained once we introduce a double commitment problem (i.e., once we assume that the bank may not be able to 
commit to negative payments in the future). Wright (2002), in turn, emphasizes the fact that banks may (implicitly) collude against defaulters, so that there may be no institution ready to offer the insurance contract. ${ }^{2}$ Amador (2002), on the other hand, stresses the fact that the cash-inadvance insurance contract would entail a time-consistent saving decision on the part of the policymaker: even if the contract is offered, the government may choose not to invest in insurance due to a short saving horizon rooted in political economy considerations. ${ }^{3}$ Ultimately, the debate appears to have gone full circle back to the insurance view.

More crucially, underlying this discussion is the belief that it is the insurance value of international debt flows that, in the first place, motivates the optimality of (some positive level of) sovereign debt from the borrower's perspective. In other words, subject to the lender's participation constraint and to the borrower's incentive compatibility constraint (which ensures repayment), a sovereign will always subscribe a debt contract under which net transfers are negatively correlated with the deviation from expected, long-run income. An interesting implication of the income-smoothing view is that default is, almost by definition, always strategic, since negative transfers are associated with positive shocks. Specifically, default should occur only in good times, when the debtor has the option of keeping the payment entirely for himself. $^{4}$

Both the assumption and the implication appear to be starkly at odds with reality. Recent anecdotal evidence suggests that bonded external debt behaves procyclically, with borrowing costs (and, alternatively, access to foreign capital) increasing during recessions and falling during expansions. Moreover, recent defaults have materialized in the context of declining growth rates, which contradicts the theory-despite the fact that default is an extreme way of bringing net transfers to zero in the event of a bad shock. ${ }^{5}$

Despite this growing belief, a test of the insurance view of debt flows procyclicality is still missing. This tests is far from trivial for a number of reasons. Crucially, it is net transfers

\footnotetext{
${ }^{2}$ Both the historical record on the workings of creditor clubs, and the evidence that defaulters are excluded from international capital markets tend to support this view.

${ }^{3}$ A related argument is made by Cole and Kehoe (1996), where the cost of default is due to negative externalities (e.g., the reputation costs on other relationships that cannot be readily insured).

${ }^{4}$ In this context, it is easy to see the distinction between willingness and ability to pay, since defaults are, by assumption, positively correlated with the latter. The more frequent case of a default during a recession calls for a more nuanced definition of those terms. We come back to this below.

${ }^{5}$ Trivially, the insurance view would entail a positive transfer in this case. As will be seen, due to the preferred creditor status of multilateral financial institutions, transfers are often negative even under default.
} 
rather than marginal costs that capture the behavior of the supply of funds (in other words, the nature of the implicit contract between lenders and the sovereign). In particular, the observed procyclicality of spreads would not be an indication of procyclicality, since one would expect, at least according to the insurance view, that countries borrow more - at a higher rate- during a recession. ${ }^{6}$

On the other hand, the literature has long recognized the difference between alternative sources of finance. For example, Bulow and Shoven (1978) have highlighted the effect of lender segmentation to distinguish between bank and bond financing, where the former is expected to be closer to the insurance blueprint than the latter. Empirically, did the cyclical pattern of debt flows change after the Brady plan launched emerging market bonded debt as an asset class — and as the primary source of private foreign funds for most emerging economies? Similarly, it is only to be expected that IFIs that are not motivated by risk-adjusted return considerations should be more countercyclical (or, at least, less procyclical) than private sources. ${ }^{7}$ Do we see this pattern in practice?

Finally, one important obstacle that has been often invoked to measure procyclicality is related to endogeneity, more precisely, the fact that international capital both reacts to and induces the business cycle, so that flow procyclicality may be reflecting the second (reverse) causality. However, endogeneity should not be an issue in the test of the insurance view, which merely states that net transfers should compensate for output declines once all the associated real effects are taken into account, enormously simplifying the empirical test.

The paper tackles this test by looking at the cyclicality of net transfers for developing countries, both in the aggregate and by distinguishing between its different components according to the lender (official and private), borrower (public and private sector) and type of debt (loans and bonds). It documents that, in most cases, transfers behave procyclically, contrary to what is assumed by the theory, with transfers being positive (negative) in years in which output exceeds (is below) its long-run trend.

\footnotetext{
${ }^{6}$ In fact, borrowing costs may work in the context of a standard debt contract as a potential channel to distribute consumption between states, by borrowing more costly in bad times at the expense of a taller bill in good times.

7 The Fund, built as an insurance mechanism against temporary balance of payment imbalances, should behave countercyclically.
} 
This finding casts doubt on the optimality of outstanding DC debt. In the absence of an insurance motive, one would need to come up with alternative motivations. Some of them are explored in the last section.

\section{The Insurance View of Sovereign Debt}

In the absence of imperfections, in a simplified Eaton-Gersovitz (1981) setup with stochastic stationary non-storable income $\mathrm{Y}=\mathrm{Y}+\varepsilon_{t}$ (where $\varepsilon_{t}$ is a zero-mean income shock), the policymaker maximizes the country's social welfare function

$$
W=E\left(\sum_{t=0}^{\infty} \beta^{t} u\left(c_{t}\right)\right)
$$

where $\beta=\frac{1}{1+r}$ is the discount factor, $u(\cdot)$ is an iso-elastic utility function, and $c_{t}=c\left(\varepsilon_{\mathrm{t}}\right)=\mathrm{Y}-$ $P\left(\varepsilon_{t}\right)$ denotes consumption at date $t$.

In this setup, a policymaker would optimally choose a borrowing policy characterized by the schedule of payments $P(\varepsilon)$ that maximizes

$$
\sum_{i=1}^{N} \pi\left(\varepsilon_{i}\right) u\left[\bar{Y}+\varepsilon_{i}-P\left(\varepsilon_{i}\right)\right]
$$

subject to the incentive-compatible constraint that ensures payment, which, assuming that a defaulting country is thereafter excluded from world capital markets, is given by

$$
\begin{aligned}
& u\left(\bar{Y}+\varepsilon_{t}\right)-u\left[\bar{Y}+\varepsilon_{t}-P\left(\varepsilon_{t}\right)\right] \leq \frac{\beta}{1-\beta}\{\mathrm{E} u[\bar{Y}+\varepsilon-P(\varepsilon)]-\mathrm{E} u[\bar{Y}+\varepsilon]\} \\
& =\frac{\beta}{1-\beta} \sum_{j=1}^{N} \pi\left(\varepsilon_{j}\right)\left\{u\left[\bar{Y}+\varepsilon_{j}-P\left(\varepsilon_{j}\right)\right]-u\left(\bar{Y}+\varepsilon_{j}\right)\right\}
\end{aligned}
$$

and the zero profit condition

$$
\sum_{i=1}^{N} \pi\left(\varepsilon_{i}\right) P_{s}\left(\varepsilon_{i}\right)=0
$$

where $\pi(\varepsilon)$ is the probability of state $\varepsilon$, the left-hand side is the short-term gain of default due to today's increased consumption, and the right-hand side denotes its long-term cost: the welfare loss associated with living in financial autarky starting tomorrow. 
It is easy to see, differentiating the incentive compatibility constraint, that $P^{\prime}\left(\varepsilon_{t}\right)>0$, namely, that the country borrows (pays) whenever the income level is below (above) its trend, so as to smooth out partially volatility in consumption.

As noted, two features of the model stand out: i) net transfers between the country and the rest of the world are countercyclical (positive when the output gap is positive and vice versa); and ii) precisely for this reason, default only occurs in good times (when the country is supposed to repay).

Needless to say, standard debt contracts are far from the contingent contract of the model. In particular, it has been noted that default episodes in bad times are an imperfect substitute of this contingent nature, as they set payments at zero. ${ }^{8}$

\section{Data and Methodological Issues}

As noted, our relevant variable is the net flow in developing economies, which we disaggregate according to each type of lender. All the empirical tests reported below employ data on net financial cross-border transfers compiled in the World Bank's Global Development Finance dataset, and normalized by the country's dollar GDP (sourced from the IMF's International Financial Statistics). The data come disaggregated by type of debt (bank, bonded, official, direct investment), original maturity (less than and more than one year) and borrower (private and public). While the focus of the exercises below is on sovereign debt, I also consider FDI and transfers to and from private borrowers to complement the analysis - and, in particular, tests for potential substitutability.

The tests also included time dummies to control for time-varying exogenous factors that are expected to influence net capital flows (global liquidity, investor sentiment, contagion from financial crises abroad, etc.). In addition, I examine the robustness of the results to the inclusion of country-specific leverage ratios (measured by the sovereign total debt to GDP ratio), economic development (proxied by per capita GDP), and access to international capital markets (proxied by an emerging market index that indicates whether or not a country is included in J. P. Morgan's EMBI Global index as of end-2003). ${ }^{9}$ All data are annual.

\footnotetext{
${ }^{8}$ Other characteristics of the original model, such as the fact that the supply of loans is bounded and upward sloping as the probability of default increases monotonically with debt service, are typically verified in practice.

${ }^{9}$ Variable definitions and sources are detailed in the Appendix.
} 
The main empirical results in the paper are based on panels regressions of the net flow series of choice on the (log-linear or HP-filtered) real GDP gap, and time and (current and past) default dummies.

\section{Empirical Results}

Tables 1 and 2 offer a first glance at the data. The first shows the summary statistics of the different disaggregated net flows considered in the paper. Table 1 sheds light on the relative economic importance of each flow type. In particular, it highlights the importance of official (non-IMF) lending and FDI, the main (and in many countries, sole) source of external flows. Here, as well as in the regressions below, for each particular type of debt flow I include countries that have at least one positive value over the period under study.

Table 2 shows the correlation matrix of these flows among each other. These numbers provide some interesting preliminary insights on the discussion. The lack of a significantly negative correlation between bond and bank flows contradicts the view that tends to view them as substitute source of finance. The same comment applies even more strongly to the significantly positive correlation between private and official flows. The absence of a positive link between (long-term) official and (typically shorter-term) IMF flows is in line with their different objectives (although at odds with the increasing participation of multilateral development banks in IMF-led rescue packages).

Not all these preliminary finings are confirmed when we turn to the baseline regressions of Table 3. There, I report the results of panel regressions of the disaggregated net flows (over GDP) on deviations from the log linear GDP trend (Table 3a) and from the HP-filtered GDP (Table 3b), controlling for country fixed effects, and including year dummies (to capture global factors such as international liquidity or episodes of global financial distress). Countries with no non-zero flow over the period of coverage are excluded. ${ }^{10}$

As can be seen, private net lending to the sovereign is strongly procyclical, as a result of procyclical and significant bank flows coupled with bond flows that display a positive but not significant correlation. This, which is in line with the lack of a significant correlation found in

\footnotetext{
${ }^{10}$ Results do not change significantly when we include zero-flow countries. This may in some cases introduce an important bias in the coefficients when large fraction of countries do not have access to a specific flow type, which most notably affects bonded debt.
} 
the previous table, it at odds with the view that bank debt, because of its centralized nature, is easier to renegotiate and thus more amenable to cyclical smoothing (Bolton and Freixas, 2000). ${ }^{11}$

By contrast, official (multilateral and bilateral) and IMF lending exhibits a strong countercyclical pattern. While this is to be expected for the latter, specialized in short-term lending to countries with balance of payments problems, the finding is not so obvious for the former, which typically entails long-term development lending that should be, at least in principle, orthogonal to the cycle. ${ }^{12}$

Total net transfers to the country are countercyclical, but significant only when we the cycle is measured using the log linear trend. Interestingly, all the smoothing effort is accounted for by official lending: private lending to the government is acyclical, and total private lending is strongly procyclical. While the sovereign debt literature is silent about the expected behavior of FDI, some analysts have suggested that it may serve as a substitute for countries with weak creditor rights and limited access to international financing. For completeness, we regress our baseline for FDI flows. The results are not conclusive, but appear to contradict the substitution view: FDI appears to be either acyclical or procyclical, mimicking other flows to the private sector.

In sum, whereas the preliminary results highlight the countercyclical nature of official flows, they are not overly supportive of the insurance view of private international flows.

\section{Defaults and Debt Flows}

There are, of course, several dimensions along which the behavior of international flows may differ. In this section, I explore what I believe are the most relevant ones.

A first aspect that should be taken into account is the incidence of (past and current) defaults, which may reduce the level of transfers contemporaneously (as a net payer chooses not to pay) and permanently (to the extent that the reputation view, which proposes that markets punish defaulters by limiting access, materializes in reality). While the impact of default on capital flows is somewhat tangential to the focus of this paper, it is interesting to examine the default effect as it has been sometimes suggested that default is indeed a way to make debt

\footnotetext{
${ }^{11}$ It needs to be noted, however, that bonded debt ratios within this group are highly diverse, with very small numbers but for a few emerging economies that have only recently gained access to international capital markets. I come back to this point in the robustness section below.

${ }^{12}$ Possible explanations include the incidence of concessional loans as last-resort lending in low-income economies and the growing participation of multilateral agencies in IMF-led rescue packages.
} 
servicing de facto contingent to the state of the world when contingent contracts are not available. On a more technical level, I need to control for the influence of default events due to their negative correlation with the output gap. To do that, I include a default dummy (equal to one when the country is rated as in default by Standard and Poor's either this or the previous year), and a past default dummy (which identifies countries that have been in default anytime between the beginning of our sample period and the year before the last). In this way, the tests capture the difference in net transfers before and after a default, but not the cross-section difference between defaulters and non-defaulters - which at any rate, is difficult to disentangle from other country-specific, time-invariant characteristics that here are subsumed in the country fixed effect. ${ }^{13}$ Table 4 replicates Table 3 with these two new variables. As can be seen, defaults are significantly and negatively correlated with bank flows (and, as expected, uncorrelated with official lending), contradicting the associated hypothesis that they proxy for contingent contracts, and possibly reflecting the fact that sovereign default are often preceded by a sudden reversion of financial flows.

Interestingly, past default is in most cases significantly and negatively correlated with debt flows (most notably, for private lending to the sovereign and total private lending to the country), suggesting that a history of defaults may affect negatively the access to external funds. This contrasts with the evidence reported in a number of studies of the impact of default on borrowing costs that find effects that are either not significant, small or extremely short-lived. ${ }^{14}$ Figure 1 presents another glance at this results, showing that the average private net transfers to the government and the country during the present decade has been substantially smaller for past defaulters than for the rest. The same applies to the residuals of the panel regressions after excluding the past default dummy.

It could be argued that the cyclicality of capital flows cannot not be properly captured at an annual frequency: attributing recessions and expansion to particular years may be inaccurate and, moreover, capital markets may take some time to accommodate. In Table 5, I repeat the exercise at the biannual frequency, using non-overlapping two-year averages, to account for delayed responses. Results are comparable to Table 4, with only one exception: IMF flows,

\footnotetext{
${ }^{13}$ As the timing of defaults and their financial effects is sometimes controversial, I prefer to use last year as the cutoff date between what is considered past and current defaults to avoid associating immediate effects to reputation aspects. However, tests controlling using the current year as cutoff date yield similar results.

${ }^{14}$ See Lindert and Morton (1989), Ozler (1993), and Flandreau and Zumer (2004) for earlier defaults, and Ades et al. (2000) and Dell'Ariccia et al. (2002) for the emerging market experience.
} 
which cease to be significant, possibly reflecting the short-term nature of crisis-driven IMF assistance.

\section{Asymmetry}

The procyclicality of capital flows to developing economies has often been attributed to sudden reversals that tend to coincide with-and reinforce-adverse macroeconomic prospects. ${ }^{15}$ Conversely, it could be argued that whereas macroeconomic expansions ignite booms in capital inflows, outflows are slowed down by renegotiation and the borrowing country's willingness to raise interest rates in order to avert default. Whatever the view, there is a priori no reason why the cyclical behavior of capital flows should be symmetric.

With this in mind, I examine whether flows behave differently during expansions and contractions by controlling separately for negative deviations from trend output (Table 6). ${ }^{16}$ As the table shows, there seems to be some support for the second view in the case of bank flows, which exhibited strong procyclicality in good times, but no significant cyclicality in the downturn. A closer inspection reveals that this result essentially reflects the behavior of bank flows in the early period, as they accompanied (and fueled) growth in developing economies in the 1970s, and reversed only gradually (in the context of several restructurings involving partial refinancing) after the stream of debt crises of the early 1980s. ${ }^{17}$ Similar pro-growth behavior characterizes FDI flows, which appear to increase markedly in good times, but do not revert as fast during downturns - a reflection of the inherent irreversibility of much of FDI.

In turn, official lending displays contrasting patterns. On the one hand, IMF transfers are strongly procyclical during recessions, as would be expected given their role as last resort lenders. On the other hand, multilateral lending displays a strong significant decline during expansions - presumably, as it is replaced by private sources - but no cyclical reaction during recessions.

\footnotetext{
${ }^{15}$ See, among others, Calvo et al. (2003) and Edwards (2005) for evidence on the link between capital account reversals and economic performance, and Gavin and Perotti (1997) for an early account on the asymmetric behavior of capital flows, where sudden reversals are sharper and more procyclical than inflows.

${ }^{16}$ For all the tests reported in the paper, similar results are obtained when the cycle is computed based on the HPfiltered trend. These results, omitted here for brevity, are available on request.

${ }^{17}$ By contrast, private bank flows in the 1990s played a minor relative to bonded debt (for emerging economies) and official lending (for non-emerging economies).
} 


\section{Country Characteristics}

Another aspect that cannot be overlooked in this analysis is the difference between more financially sophisticated emerging economies with access to private flows, and less sophisticated developing economies that rely largely on official lending and FDI. In Table 7, I split the sample into emerging and non-emerging markets, where the former consist of the 32 countries included in J.P. Morgan's Global Emerging Market portfolio as of end-2003. As can be seen, the two groups differ markedly. Whereas total sovereign flows are countercyclical for non-emerging economies, the opposite is true for emerging ones. However, the distinction does not reflect differential behavior across groups, but rather the result of the diverse composition of the borrowing within each group. While private lenders behave procyclically in both cases, countercyclical official lending dominates the results for the non-emerging economies, generally more limited in their financing sources. Interestingly, non-IMF official lending is strongly countercyclical in the latter case, but not in the former, suggesting that, despite its long-term horizon, it does provide some short-term insurance against cyclical fluctuations in countries with limited access to private sources.

A similar, partially overlapping distinction across countries relates to their level of income, often associated with their degree of institutional and financial development, a factor that presumably favors not only access to capital but also a less sensitive reaction to adverse shocks. In Table 8, I explore the influence of the country's income on the behavior of capital flows, by splitting the sample into a high-income and a low-income group, according the whether their per capita GDP is above or below the sample mean. Reassuringly, the results are largely consistent with those in Table 7. In particular, while private lending is generally procyclical, official lending is again strongly countercyclical for low-income economies, determining the cyclical nature of sovereign finance for these group of countries.

In Table 9, I examine another country-specific factor that may help explain procycicality: the degree of indebtedness, as measured by the ratio of total debt over GDP. The fact that some developing countries have been historically highly leveraged may explain why cyclical downturns deteriorate the country's perceived credit risk and, in turn, the supply of external funds. To test whether this has been a factor, I include a high debt dummy, which takes a value of one whenever the country's total external debt ratio is above the sample median, and interact the dummy with the output gap variable. While the interaction has the expected positive sign 
(with leverage increasing the degree of procyclicality), it is not significant for either bank or bonded debt. Somewhat surprisingly, the main impact is on official and IMF lending, which become acyclical for high-debt countries. Also puzzling is the effect on total private credit to the country, which goes from procyclical to acyclical for highly indebted countries. Overall, however, the hypothesis that the procyclicality of lending to the sovereign reflects excessive indebtedness is not supported by the data.

\section{Substitutes or Complements?}

So far, I have analyzed the behavior of cross-border transfers associated with different types of capital flows independently. However, there are reasons to believe - as has been highlighted in the literature - that some of these flows substitute each other. The natural example is provided by the IMF (or, more generally, official lending) and private lenders, as the pulling out of the latter typically triggers the intervention of the former. Alternatively, it has been argued that official (particularly IMF) lending may provide a "seal of approval" due to their superior information about the country or their capacity to condition domestic policies, thereby crowding in private funds. ${ }^{18}$

In turn, the gradual substitution of bank debt by global bonds at the start of the emerging market phenomenon has been well-documented. ${ }^{19}$ Was this substitution a once-and-for-all consequence of the debt crises of the 1980s, or a recurrent phenomenon visible in recent years? Finally, it has been stressed that FDI- presumably less exposed to credit risk-may play a role as a substitute investment channel in developing countries in turbulent times. ${ }^{20}$

With this question in mind, in Table 10 I have a first look at how these flows relate with each other. First, to check whether official flows substitute for private flows, I include total private flows as an additional control in the official flows regression. While the sign is negative as expected, the link is not significant at conventional levels (although the p-value for IMF flows is $12 \%$ ). Similarly, to check whether bonded debt took the place of bank debt in the $90 \mathrm{~s}$, I add bank flows to the regression of bonded debt transfers. Again, no significant link is found.

What about the catalytic role of official lending? In column 3, I rerun the regression of private lending to the sovereign adding IMF net transfers. Arguably, the coefficient on IMF

\footnotetext{
${ }^{18}$ See Rodrick (1995) and Morris and Shin (2003).

${ }^{19}$ See, among others, Cowan, Levy Yeyati, Panizza and Sturzenegger (2006).

${ }^{20}$ See Fernández Arias and Hausmann (2000).
} 
flows captures the net effect of two countervailing factors: the positive catalytic effect mentioned above, and the negative signaling effect of resorting to the IMF as lender of last resort (and, more generally, the perception of mounting credit risk). While the contribution of each effect is hard to identify at this relatively low frequency, the net effect fails to be significant. More interesting is the result for non-IMF official credit, which displays a significant positive coefficient, in line with the catalytic view. ${ }^{21}$ However, somewhat at odds with the crowding-in view, this link is strictly contemporaneous (no significant link is found with the lag of IMF flows) hinting at other common factors (including changes in the country's demand for funds) rather than a catalytic effect as a potential explanation.

Finally, to study the link between financial flows and FDI, I add total lending from private creditors to the FDI regression. This time, the prior is confirmed: FDI increases when portfolio flows falter, in line with the substitution view.

\section{Optimal Debt?}

Despite its popularity, insurance against transitory income shocks is not the only rationale that has been suggested in the literature (which also includes, most notably, the intertemporal substitution motive in economies with better growth opportunities). I did not attempt to test here the alternative stories. Rather, I wanted to document the fact that the standard insurance view is not consistent with the observed behavior of private lending to the sovereign.

In light of this new evidence, the long-standing question of the sovereign debt literature -namely, why would the sovereign repay its debt—remains open. Moreover, even if an answer were to be found, as sometimes suggested, in the presence of sanctions or externalities of default, one would still need to answer why the sovereign would borrow in the first place, if not to smooth consumption. In other words, is the optimal amount of debt zero?

One possible explanation of procyclical cross-border flows is procyclical borrowing, itself the suboptimal result of a government moral hazard problem. For example, the combination of procyclical financial constraints (associated with the country's ability to pay) and a myopic polic maker could explain why a government would borrow each period as much as the market would allow him to (Rochet, 2006). This political economy approach to debt flows is

\footnotetext{
${ }^{21}$ This confirms results reported by Fernández-Arias and Powell (2006).
} 
certainly a fruitful line for future empirical research. At any rate, it only reinforces the suspicion that sovereign debt in developing economies is, if not totally superfluous, suboptimally high.

The second main finding of the paper is the fact that net official flows exhibits in most cases a countercyclical pattern, particularly vis-à-vis financially unsophisticated, low-income economies. This sheds new light on the role of the IFIs as implicit country insurers. More importantly, it suggests that the very insurance view that has been used to explain why a sovereign repays its debts with private lenders may rationalize the remarkable efficacy displayed by multilateral financial institutions in enforcing their implicit "preferred creditor status": countries may be playing the reputation game with the only lender that can credibly commit to lend in bad times.

The objective of the paper was very specific: to probe the consistency of the conventional explanation of the sovereign's incentives to repay. Its findings cast doubt on this traditional view, and leaves open many relevant questions: Is there a link between flow cyclicality and default risk? Is there an optimal type of lender? How this evidence compares with that of developed economies? Why borrow? The answers to these questions are crucial to advance in our understanding of sovereign debt markets. 


\section{References}

Ades, A., F. Kaune, P. Leme, R. Masih, and D. Tenengauzer. 2000. "Introducing GS-ESS: A New Framework for Assessing Fair Value in Emerging Markets Hard-Currency Debt.” New York, United States: www.goldmansachs.com.

Amador, M. 2003. “A Political Model of Sovereign Debt Repayment.” Stanford, United States: Stanford University. Mimeographed document.

Bolton, P., and X. Freixas. 2000. "Equity, Bonds and Bank Debt: Capital Structure and Financial Market Equilibrium under Asymmetric Information." Journal of Political Economy 108(2): 324-51.

Bulow, J., and K. Rogoff. 1989a. "Sovereign Debt: Is to Forgive to Forget?" American Economic Review 79(1): 43-50.

----. 1989b. “A Constant Recontracting Model of Sovereign Debt.” Journal of Political Economy 97(1): 155-78.

Bulow, J., and J. Shoven. 1978. "The Bankruptcy Decision." Bell Journal of Economics 9(2): $437-456$.

Calvo, G., A. Izquierdo and E. Talvi. 2003. "Sudden Stops, the Real Exchange Rate, and Fiscal Sustainability: Argentina's Lessons.” NBER Working Paper 9828. Cambridge, United States: National Bureau of Economic Research.

Cole, H., and T. Kehoe. 1996. "A Self-Fulfilling Model of Mexico's 1994-1995 Debt Crisis." Journal of International Economics 41(3-4): 309-330.

Cowan, K., E. Levy Yeyati, U. Panizza and F. Sturzenegger. 2006. "Public Debt in the Americas.” Research Department Working Paper 561. Washington, DC, United States: Inter-American Development Bank.

Dell'Ariccia, G., I. Schnabel and J. Zettelmeyer. 2002. "Moral Hazard and International Crisis Lending: A Test.” Working Paper 02/181. Washington, DC, United States: International Monetary Fund.

Eaton, J., and M. Gersovitz. 1981. "Debt with Potential Repudiation: Theoretical and Empirical Analysis." Review of Economic Studies 48(2): 289-309.

Edwards, S. 2005. "Capital Controls, Sudden Stops and Current Account Reversals." NBER Working Paper 11170. Cambridge, United States: National Bureau of Economic Research. 
E. Fernández-Arias and R. Hausmann. 2000. "Foreign Direct Investment: Good Cholesterol?" Research Department Working Paper 417. Washington, DC, United States: InterAmerican Development Bank.

E. Fernández-Arias and A. Powell. 2006.

Flandreau, M., and F. Zumer. 2004. The Making of Global Finance. Paris, France: Organisation for Economic Co-operation and Development.

Gavin, M., and R. Perotti. 1997. "Fiscal Policy in Latin America." In: B. Bernanke and J. Rotemberg, editors. NBER Macro Annual. Cambridge, United States: MIT Press.

Kletzer, K., and B. Wright. 2000. "Sovereign Debt as Intertemporal Barter." American Economic Review 90(3): 621-639.

Lindert, P., and P. Morton. 1989. "How Sovereign Debt Has Worked." In: J. Sachs, editor. Developing Country Debt and the World Economy. Chicago, United States: National Bureau of Economic Research/University of Chicago Press.

Ozler, S. 1993. "Have Commercial Banks Ignored History?” American Economic Review 83(3): 608-20.

Rochet, J.C. 2006. “Sovereign Debt: Why Do Countries Borrow So Much?” Toulouse, France: IDEI-Université Toulouse I. Mimeographed document.

Rodrik., D. 1995. “Why is there Multilateral Lending?” NBER Working Paper 5160. Cambridge, United States: National Bureau of Economic Research.

Wright, M.L.J. 2001. "Reputations and Sovereign Debt." Cambridge, United States: Massachusetts Institute of Technology. Manuscript. 


\section{Appendix Table 1. Variable definition and sources}

\begin{tabular}{|c|c|c|}
\hline Variable & Description & Source \\
\hline Banks & $\begin{array}{l}\text { Net transfers on public and publicly guaranteed long-term } \\
\text { commercial bank loans from private banks and other private financial } \\
\text { institutions. }\end{array}$ & GDF (2006) \\
\hline Bonds & $\begin{array}{l}\text { Net transfers on Public and publicly guaranteed long-term debt from } \\
\text { bonds that are either publicly issued or privately placed. }\end{array}$ & GDF (2006) \\
\hline $\begin{array}{l}\text { Private } \\
\text { Creditors }\end{array}$ & $\begin{array}{l}\text { Net transfers on public and publicly guaranteed long-term debt from } \\
\text { private creditors. Includes bonds, commercial bank loans, and other } \\
\text { private credits. }\end{array}$ & GDF (2006) \\
\hline Official & $\begin{array}{l}\text { Net transfers on public and publicly guaranteed long-term debt from } \\
\text { official creditors. Includes loans from international organizations } \\
\text { (multilateral loans) and loans from governments (bilateral loans). }\end{array}$ & GDF (2006) \\
\hline IMF & IMF, net flows on concessional and nonconcessional debt.* & GDF (2006) \\
\hline $\begin{array}{l}\text { Total } \\
\text { Sovereign }\end{array}$ & $\begin{array}{l}\text { Net transfers on Public and publicly guaranteed long-term. Public } \\
\text { debt is an external obligation of a public debtor. Publicly guaranteed } \\
\text { debt is an external obligation of a private debtor that is guaranteed for } \\
\text { repayment by a public entity. }\end{array}$ & GDF (2006) \\
\hline Total Private & Net transfers, total debt, private creditors & GDF (2006) \\
\hline FDI & $\begin{array}{l}\text { Net change in foreign investment, defined as investment that is made } \\
\text { to acquire a lasting management interest in an enterprise operating in } \\
\text { a country other than that of the investor. }\end{array}$ & GDF (2006) \\
\hline $\begin{array}{l}\text { Total debt } \\
\text { stock / gdp }\end{array}$ & $\begin{array}{l}\text { Debt stock, total over gdp in current US dollars. Includes public and } \\
\text { publicly guaranteed long-term debt, private nonguaranteed long-term } \\
\text { debt, the use of IMF credit, and estimated short-term debt. }\end{array}$ & GDF (2006) \\
\hline $\begin{array}{l}\text { Real gdp per } \\
\text { capita }\end{array}$ & GDP per capita, constant prices in national currency (units). (WEO) & $\begin{array}{r}\text { WEO } \\
(2006)\end{array}$ \\
\hline $\begin{array}{l}\text { Output Gap } \\
(\log )\end{array}$ & $\begin{array}{l}\text { Ratio of the difference between real gdp per capita and it's trend } \\
\text { (linear or Hodrick Prescott filtered) to real gdp per capita. }\end{array}$ & \\
\hline default & $\begin{array}{l}\text { Dummy that equals } 1 \text { if the country is in default on any of its } \\
\text { sovereign obligations default in the year or the previous year }\end{array}$ & $\begin{array}{l}\text { Standard \& } \\
\text { Poor's }\end{array}$ \\
\hline Past default & $\begin{array}{l}\text { Dummy that equals } 1 \text { if the country was in default on any of its } \\
\text { sovereign obligations default in sometime before the previous year. }\end{array}$ & $\begin{array}{l}\text { Standard \& } \\
\text { Poor's }\end{array}$ \\
\hline
\end{tabular}

* Excluding those made in the reserve tranche. 
Table 1: Summary statistics of transfers by type (as \% of GDP)

\begin{tabular}{lccccc}
\hline Variable & $\mathbf{N}$ & Mean & Median & Std. Dev & Skewness \\
\hline Banks & 3184 & -0.6557428 & -0.4246571 & 174.6134 & 3.213708 \\
Bonds & 2009 & 7.934266 & -0.0144259 & 159.6338 & 10.63847 \\
Private creditors & 3671 & 16.56829 & -1.802932 & 261.6306 & 4.709938 \\
Official & 3809 & 191.1979 & 80.90614 & 480.3967 & 8.957562 \\
IMF & 1589 & 0.1706426 & 0 & 1.193137 & 6.06866 \\
Total & 3820 & 206.5731 & 107.4 & 583.389 & 7.416267 \\
Total private creditors & 3672 & 20.62234 & -1.536431 & 298.533 & 3.535373 \\
FDI & 3679 & 233.9913 & 91.20673 & 527.9115 & 8.896336 \\
\hline
\end{tabular}


Table 2a: Correlation matrix - Transfers by type (as \% of GDP; demeaned by their country mean)

\begin{tabular}{|c|c|c|c|c|c|c|c|}
\hline & Banks & Bonds & $\begin{array}{l}\text { Private } \\
\text { creditors }\end{array}$ & Official & IMF & Total & $\begin{array}{c}\text { Total } \\
\text { private } \\
\text { creditors }\end{array}$ \\
\hline Banks & 1 & & & & & & \\
\hline Bonds & 0.0039 & 1 & & & & & \\
\hline $\begin{array}{l}\text { Private } \\
\text { creditors }\end{array}$ & $-0.0408^{* *}$ & $0.0611 * * *$ & 1 & & & & \\
\hline Official & -0.003 & 0.0049 & $0.0666^{* * *}$ & 1 & & & \\
\hline IMF & $0.166 * * *$ & -0.0103 & -0.0067 & -0.0113 & 1 & & \\
\hline Total & 0.003 & 0.0019 & -0.0008 & $0.0972 * * *$ & -0.0019 & 1 & \\
\hline $\begin{array}{l}\text { Total } \\
\text { private }\end{array}$ & $-0.0415^{* *}$ & $0.0613 * * *$ & $0.8633 * * *$ & -0.0039 & -0.0078 & -0.0023 & 1 \\
\hline FDI & 0.0001 & -0.0019 & -0.0024 & 0.0012 & 0.0007 & -0.0004 & -0.0018 \\
\hline
\end{tabular}


Table 3a: The cyclicality of debt flows.

(based on a log linear trend)

\begin{tabular}{|c|c|c|c|c|c|c|c|c|}
\hline & (1) & (2) & (3) & (4) & (5) & (6) & (7) & (8) \\
\hline & \multicolumn{6}{|l|}{ Sovereign } & \multirow[b]{2}{*}{$\begin{array}{l}\text { Total } \\
\text { private }\end{array}$} & \multirow[b]{2}{*}{ FDI } \\
\hline & Banks & Bonds & $\begin{array}{l}\text { Private } \\
\text { creditors }\end{array}$ & Official & IMF & Total & & \\
\hline \multirow[t]{2}{*}{ output gap } & $1.243 * * *$ & 0.335 & $1.140 * * *$ & $-2.205 * * *$ & $-1.180 * * *$ & -1.302 & $0.484 * * *$ & $3.392 * *$ \\
\hline & $(0.299)$ & $(0.312)$ & $(0.340)$ & $(0.800)$ & $(0.405)$ & $(0.900)$ & $(0.132)$ & $(1.604)$ \\
\hline \multirow[t]{2}{*}{ Constant } & 0.296 & 0.904 & $1.105^{*}$ & $1.842 * * *$ & $0.483 *$ & $2.810 * * *$ & $0.302 *$ & $2.106 * * *$ \\
\hline & $(0.207)$ & $(0.929)$ & $(0.591)$ & $(0.345)$ & $(0.269)$ & $(0.630)$ & $(0.170)$ & $(0.622)$ \\
\hline Observations & 3175 & 2000 & 3662 & 3800 & 1589 & 3811 & 3832 & 3660 \\
\hline R-squared & 0.14 & 0.17 & 0.13 & 0.34 & 0.14 & 0.28 & 0.19 & 0.39 \\
\hline \multicolumn{9}{|c|}{$\begin{array}{l}\text { Robust standard errors in parentheses } \\
* \text { significant at } 10 \% ; * * \text { significant at } 5 \% ; * * * \text { significant at } 1 \% \\
121 \text { countries. }\end{array}$} \\
\hline \multicolumn{9}{|c|}{$\begin{array}{l}\text { Table 3b: The cyclicality of debt flows. } \\
\text { (based on a HP trend) }\end{array}$} \\
\hline & (1) & $(2)$ & (3) & (4) & (5) & (6) & (7) & (8) \\
\hline & \multicolumn{6}{|l|}{ Sovereign } & & \\
\hline & Banks & Bonds & $\begin{array}{l}\text { Private } \\
\text { creditors }\end{array}$ & Official & IMF & Total & $\begin{array}{l}\text { Total } \\
\text { private }\end{array}$ & FDI \\
\hline \multirow[t]{2}{*}{ output gap } & $2.670 * * *$ & -0.273 & $2.565 * * *$ & $-2.794 * * *$ & $-3.750 * * *$ & -0.343 & $1.393 * * *$ & -0.325 \\
\hline & $(0.652)$ & $(0.512)$ & $(0.702)$ & $(1.080)$ & $(0.795)$ & $(1.364)$ & $(0.334)$ & $(2.914)$ \\
\hline \multirow[t]{2}{*}{ Constant } & 0.305 & 0.865 & $1.099 *$ & $1.913 * * *$ & $0.515^{*}$ & $2.887 * * *$ & $0.309 *$ & $1.838 * * *$ \\
\hline & $(0.208)$ & $(0.926)$ & $(0.590)$ & $(0.338)$ & $(0.264)$ & $(0.626)$ & $(0.169)$ & $(0.613)$ \\
\hline Observations & 3175 & 2000 & 3662 & 3800 & 1589 & 3811 & 3832 & 3660 \\
\hline R-squared & 0.14 & 0.17 & 0.14 & 0.34 & 0.16 & 0.28 & 0.19 & 0.39 \\
\hline
\end{tabular}

Robust standard errors in parentheses

$*$ significant at 10\%; ** significant at 5\%; *** significant at $1 \%$

121 countries. 
Table 4a: The cyclicality of debt flows - Defaults (based on a log linear trend)

\begin{tabular}{|c|c|c|c|c|c|c|c|c|}
\hline & (1) & (2) & (3) & (4) & $(5)$ & (6) & $(7)$ & $(8)$ \\
\hline & \multicolumn{8}{|l|}{ Sovereign } \\
\hline & Banks & Bonds & $\begin{array}{l}\text { Private } \\
\text { creditors }\end{array}$ & Official & IMF & Total & $\begin{array}{l}\text { Total } \\
\text { private }\end{array}$ & FDI \\
\hline output gap & $\begin{array}{l}0.927 * * * \\
(0.293)\end{array}$ & $\begin{array}{l}0.371 \\
(0.393)\end{array}$ & $\begin{array}{l}0.872 * * \\
(0.344)\end{array}$ & $\begin{array}{l}-2.232 * * * \\
(0.804)\end{array}$ & $\begin{array}{l}-1.204 * * * \\
(0.400)\end{array}$ & $\begin{array}{l}-1.567 * \\
(0.916)\end{array}$ & $\begin{array}{l}0.434 * * * \\
(0.130)\end{array}$ & $\begin{array}{l}3.313 * * \\
(1.637)\end{array}$ \\
\hline past default & $\begin{array}{l}-0.485 * * * \\
(0.134)\end{array}$ & $\begin{array}{l}-0.097 \\
(0.117)\end{array}$ & $\begin{array}{l}-0.994 * * * \\
(0.179)\end{array}$ & $\begin{array}{l}0.087 \\
(0.230)\end{array}$ & $\begin{array}{l}-0.746^{*} \\
(0.423)\end{array}$ & $\begin{array}{l}-0.986^{* * * *} \\
(0.294)\end{array}$ & $\begin{array}{l}0.212 * * * \\
(0.082)\end{array}$ & $\begin{array}{l}-0.289 \\
(0.214)\end{array}$ \\
\hline default & $-0.368 * * *$ & 0.080 & $-0.364 * *$ & -0.161 & 0.071 & $-0.560 * *$ & $0.334 * * *$ & -0.067 \\
\hline Constant & $\begin{array}{l}(0.119) \\
0.245 \\
(0.220)\end{array}$ & $\begin{array}{l}(0.203) \\
0.888 \\
(0.918)\end{array}$ & $\begin{array}{l}(0.177) \\
1.068 * \\
(0.594)\end{array}$ & $\begin{array}{l}(0.187) \\
1.869^{* * *} \\
(0.345)\end{array}$ & $\begin{array}{l}(0.131) \\
0.839 * * \\
(0.419)\end{array}$ & $\begin{array}{l}(0.261) \\
2.829 * * * \\
(0.632)\end{array}$ & $\begin{array}{l}(0.064) \\
0.357 * * \\
(0.171)\end{array}$ & $\begin{array}{l}(0.174) \\
2.077 * * * \\
(0.622)\end{array}$ \\
\hline Observations & 3175 & 2000 & 3662 & 3800 & 1589 & 3811 & 3832 & 3660 \\
\hline R-squared & 0.15 & 0.17 & 0.15 & 0.34 & 0.15 & 0.28 & 0.19 & 0.39 \\
\hline
\end{tabular}

Robust standard errors in parentheses

$*$ significant at $10 \%$; ** significant at $5 \%$; *** significant at $1 \%$

121 countries.

Table 4b: The cyclicality of debt flows - Defaults (based on a HP trend)

\begin{tabular}{|c|c|c|c|c|c|c|c|c|}
\hline & $(1)$ & (2) & (3) & (4) & (5) & (6) & (7) & (8) \\
\hline & \multicolumn{8}{|l|}{ Sovereign } \\
\hline & Banks & Bonds & $\begin{array}{l}\text { Private } \\
\text { creditors }\end{array}$ & Official & IMF & Total & $\begin{array}{l}\text { Total } \\
\text { private }\end{array}$ & FDI \\
\hline \multirow[t]{2}{*}{ output gap } & $2.386 * * *$ & -0.220 & $2.330 * * *$ & $-2.831 * * *$ & $-3.617 * * *$ & -0.619 & $1.289 * * *$ & -0.454 \\
\hline & $(0.647)$ & $(0.565)$ & $(0.699)$ & (1.087) & $(0.824)$ & $(1.376)$ & $(0.330)$ & $(2.931)$ \\
\hline \multirow[t]{2}{*}{ past default } & $-0.511 * * *$ & -0.101 & $-1.018 * * *$ & 0.129 & -0.624 & $-0.957 * * *$ & $0.204 * *$ & $-0.399 *$ \\
\hline & $(0.134)$ & $(0.112)$ & $(0.178)$ & $(0.233)$ & $(0.432)$ & $(0.296)$ & $(0.082)$ & $(0.210)$ \\
\hline \multirow[t]{2}{*}{ default } & $-0.370 * * *$ & 0.052 & $-0.361 * *$ & -0.128 & 0.074 & $-0.519 * *$ & - & -0.188 \\
\hline & $(0.119)$ & $(0.195)$ & $(0.177)$ & $(0.184)$ & $(0.129)$ & $(0.259)$ & $\begin{array}{l}0.331 * * * \\
(0.064)\end{array}$ & $(0.163)$ \\
\hline \multirow[t]{2}{*}{ Constant } & 0.259 & 0.853 & $1.070^{*}$ & $1.938 * * *$ & $0.808^{*}$ & $2.912 * * *$ & $0.363 * *$ & $1.812 * * *$ \\
\hline & $(0.221)$ & $(0.909)$ & $(0.593)$ & $(0.338)$ & $(0.418)$ & $(0.627)$ & $(0.170)$ & $(0.614)$ \\
\hline Observations & 3175 & 2000 & 3662 & 3800 & 1589 & 3811 & 3832 & 3660 \\
\hline R-squared & 0.15 & 0.17 & 0.15 & 0.34 & 0.16 & 0.28 & 0.20 & 0.39 \\
\hline
\end{tabular}

Robust standard errors in parentheses

* significant at $10 \%$; * significant at $5 \%$; *** significant at $1 \%$ 121 countries. 
Table 5: Lagged effects - Two year averages

(based on a log linear trend)

\begin{tabular}{|c|c|c|c|c|c|c|c|c|}
\hline & (1) & (2) & (3) & (4) & (5) & (6) & $(7)$ & $(8)$ \\
\hline & \multicolumn{6}{|l|}{ Sovereign } & \multirow[b]{2}{*}{$\begin{array}{l}\text { Total } \\
\text { private }\end{array}$} & \multirow[b]{2}{*}{ FDI } \\
\hline & Banks & Bonds & $\begin{array}{l}\text { Private } \\
\text { creditors }\end{array}$ & Official & IMF & Total & & \\
\hline \multirow[t]{2}{*}{ output gap } & $1.176^{* *}$ & 0.569 & $1.313^{* *}$ & $-2.027 *$ & -0.400 & -1.139 & 0.232 & 3.106 \\
\hline & $(0.466)$ & $(0.381)$ & $(0.542)$ & $(1.179)$ & $(0.703)$ & $(1.361)$ & $(0.144)$ & $(2.213)$ \\
\hline \multirow[t]{2}{*}{ past default } & $-0.543 * * *$ & -0.026 & $-1.009 * * *$ & 0.376 & -1.208 & $-0.754 *$ & $0.254 * *$ & -0.348 \\
\hline & $(0.186)$ & $(0.127)$ & $(0.244)$ & $(0.300)$ & $(0.976)$ & $(0.397)$ & $(0.111)$ & $(0.291)$ \\
\hline \multirow[t]{2}{*}{ default } & -0.318 & 0.049 & -0.362 & -0.291 & 0.198 & $-0.676^{*}$ & $-0.417 * * *$ & 0.021 \\
\hline & $(0.195)$ & $(0.168)$ & $(0.236)$ & $(0.270)$ & (0.299) & $(0.383)$ & $(0.088)$ & $(0.248)$ \\
\hline \multirow[t]{2}{*}{ Constant } & $0.473 * * *$ & 0.419 & $0.776^{* *}$ & $2.189 * * *$ & 0.940 & $2.812 * * *$ & 0.299 & $1.794 * * *$ \\
\hline & $(0.177)$ & $(0.476)$ & $(0.307)$ & $(0.446)$ & $(0.622)$ & $(0.508)$ & $(0.192)$ & $(0.511)$ \\
\hline Observations & 1427 & 894 & 1647 & 1714 & 632 & 1718 & 1728 & 1644 \\
\hline R-squared & 0.24 & 0.22 & 0.21 & 0.45 & 0.29 & 0.37 & 0.18 & 0.49 \\
\hline
\end{tabular}


Table 6: Asymmetries (based on a log linear trend)

\begin{tabular}{|c|c|c|c|c|c|c|c|c|}
\hline & (1) & (2) & (3) & (4) & $(5)$ & (6) & (7) & $(8)$ \\
\hline & \multicolumn{8}{|l|}{ Sovereign } \\
\hline & Banks & Bonds & $\begin{array}{l}\text { Private } \\
\text { creditors }\end{array}$ & Official & IMF & Total & $\begin{array}{l}\text { Total } \\
\text { private }\end{array}$ & FDI \\
\hline \multirow[t]{2}{*}{ output gap } & $3.633 * * *$ & 0.878 & 0.727 & $-6.662 * * *$ & 0.448 & -5.867 & 0.116 & $8.538 * * *$ \\
\hline & $(0.868)$ & $(0.684)$ & $(1.547)$ & $(2.318)$ & $(0.807)$ & $(3.573)$ & $(0.430)$ & $(3.157)$ \\
\hline \multirow[t]{2}{*}{ output gap_neg } & $-4.600 * * *$ & -0.866 & 0.225 & $6.836^{*}$ & $-2.454 * *$ & 6.629 & 0.491 & -8.206 \\
\hline & $(1.264)$ & $(1.203)$ & $(2.487)$ & $(3.834)$ & $(1.213)$ & $(5.760)$ & $(0.557)$ & $(5.263)$ \\
\hline \multirow[t]{3}{*}{ past default } & $-0.468 * * *$ & -0.094 & - & 0.036 & $-0.731 *$ & $-1.034 * * *$ & $0.209 * *$ & -0.215 \\
\hline & & & $0.996 * * *$ & & & & & \\
\hline & $(0.133)$ & $(0.115)$ & $(0.176)$ & $(0.225)$ & $(0.420)$ & $(0.286)$ & $(0.082)$ & $(0.211)$ \\
\hline \multirow[t]{2}{*}{ default } & $-0.373 * * *$ & 0.080 & $-0.365 * *$ & -0.168 & 0.081 & $-0.567 * *$ & - & -0.064 \\
\hline & (0.119) & $(0.203)$ & $(0.177)$ & $(0.186)$ & $(0.132)$ & $(0.261)$ & $\begin{array}{l}0.334 * * * \\
(0.064)\end{array}$ & $(0.174)$ \\
\hline \multirow[t]{2}{*}{ Constant } & -0.000 & 0.839 & $1.080^{*}$ & $2.248 * * *$ & $0.721 *$ & $3.201 * * *$ & $0.385 * *$ & $1.618 * *$ \\
\hline & $(0.231)$ & $(0.953)$ & $(0.621)$ & $(0.427)$ & $(0.403)$ & $(0.739)$ & $(0.177)$ & $(0.712)$ \\
\hline Observations & 3175 & 2000 & 3662 & 3800 & 1589 & 3811 & 3832 & 3660 \\
\hline R-squared & 0.16 & 0.17 & 0.15 & 0.34 & 0.16 & 0.28 & 0.19 & 0.40 \\
\hline output_neg & -0.9671 & 0.0125 & 0.9520 & 0.1740 & -2.0063 & 0.7623 & 0.6074 & 0.3323 \\
\hline (total effect) & {$[0.0634]$} & {$[0.9863]$} & {$[0.3554]$} & {$[0.9222]$} & {$[0.0015]$} & {$[0.7545]$} & {$[0.0013]$} & {$[0.9093]$} \\
\hline
\end{tabular}

Robust standard errors in parentheses. p-value of F-test in brackets.

$*$ significant at 10\%; $* *$ significant at 5\%; *** significant at $1 \%$

121 countries. 
Table 7a: Emerging economies (based on a log linear trend)

\begin{tabular}{|c|c|c|c|c|c|c|c|c|}
\hline & (1) & (2) & (3) & (4) & (5) & (6) & (7) & (8) \\
\hline & \multicolumn{8}{|l|}{ Sovereign } \\
\hline & Banks & Bonds & $\begin{array}{l}\text { Private } \\
\text { creditors }\end{array}$ & Official & IMF & Total & $\begin{array}{l}\text { Total } \\
\text { private }\end{array}$ & FDI \\
\hline output gap & $\begin{array}{l}0.691 \\
(0.469)\end{array}$ & $\begin{array}{l}0.864 \\
(0.621)\end{array}$ & $\begin{array}{l}2.051 * * * \\
(0.749)\end{array}$ & $\begin{array}{l}0.345 \\
(0.365)\end{array}$ & $\begin{array}{l}-0.124 \\
(2.320)\end{array}$ & $\begin{array}{l}2.397 * * * \\
(0.896)\end{array}$ & $\begin{array}{l}1.356 * * * \\
(0.407)\end{array}$ & $\begin{array}{l}0.564 \\
(0.511)\end{array}$ \\
\hline past default & & -0.163 & $-1.099 * * *$ & 0.032 & -2.369 & - & $0.341 * *$ & $0.286^{*}$ \\
\hline & $\begin{array}{l}0.553 * * * \\
(0.199)\end{array}$ & $(0.125)$ & $(0.312)$ & $(0.195)$ & $(1.475)$ & $\begin{array}{l}1.064 * * * \\
(0.388)\end{array}$ & $(0.170)$ & $(0.163)$ \\
\hline default & - & - & $-0.693 * * *$ & $0.335^{* * *}$ & 0.230 & -0.365 & - & - \\
\hline & $\begin{array}{l}0.533 * * * \\
(0.135)\end{array}$ & $\begin{array}{l}0.316^{* *} \\
(0.123)\end{array}$ & $(0.214)$ & $(0.122)$ & $(0.284)$ & $(0.254)$ & $\begin{array}{l}0.530 * * * \\
(0.129)\end{array}$ & $\begin{array}{l}0.570 * * * \\
(0.150)\end{array}$ \\
\hline Constant & $\begin{array}{l}0.084 \\
(0.132)\end{array}$ & $\begin{array}{l}0.070 \\
(0.107)\end{array}$ & $\begin{array}{l}0.447^{*} \\
(0.245)\end{array}$ & $\begin{array}{l}0.736^{* * *} \\
(0.211)\end{array}$ & $\begin{array}{l}1.488 \\
(1.135)\end{array}$ & $\begin{array}{l}1.187^{* * *} \\
(0.348)\end{array}$ & $\begin{array}{l}0.326^{* *} \\
(0.163)\end{array}$ & $\begin{array}{l}1.036^{* * *} \\
(0.277)\end{array}$ \\
\hline Observations & 934 & 870 & 960 & 955 & 402 & 960 & 960 & 972 \\
\hline R-squared & 0.33 & 0.31 & 0.31 & 0.35 & 0.20 & 0.37 & 0.26 & 0.46 \\
\hline
\end{tabular}

Robust standard errors in parentheses

$*$ significant at $10 \%$;* significant at $5 \%$; $* *$ significant at $1 \%$

31 countries.

Table 7b: Non-Emerging economies (based on a log linear trend)

\begin{tabular}{|c|c|c|c|c|c|c|c|c|}
\hline & (1) & (2) & (3) & (4) & (5) & (6) & (7) & (8) \\
\hline & \multicolumn{6}{|c|}{ Sovereign } & \multirow[b]{2}{*}{$\begin{array}{l}\text { Total } \\
\text { private }\end{array}$} & \multirow[b]{2}{*}{ FDI } \\
\hline & Banks & Bonds & $\begin{array}{l}\text { Private } \\
\text { creditors }\end{array}$ & Official & IMF & Total & & \\
\hline output gap & $\begin{array}{l}0.958 * * * \\
(0.358)\end{array}$ & $\begin{array}{l}0.248 \\
(0.543)\end{array}$ & $\begin{array}{l}0.629 \\
(0.385)\end{array}$ & $\begin{array}{l}-2.752 * * * \\
(0.980)\end{array}$ & $\begin{array}{l}-1.242 * * * \\
(0.376)\end{array}$ & $\begin{array}{l}-2.352 * * \\
(1.102)\end{array}$ & $\begin{array}{l}0.231 * \\
(0.132)\end{array}$ & $\begin{array}{l}3.884 * * \\
(1.969)\end{array}$ \\
\hline past default & $\begin{array}{l}-0.432 * * \\
(0.173)\end{array}$ & $\begin{array}{l}-0.072 \\
(0.161)\end{array}$ & $\begin{array}{l}-0.940^{* * *} \\
(0.217)\end{array}$ & $\begin{array}{l}0.115 \\
(0.306)\end{array}$ & $\begin{array}{l}-0.214 \\
(0.198)\end{array}$ & $\begin{array}{l}-0.913 * * \\
(0.378)\end{array}$ & $\begin{array}{l}0.171^{*} \\
(0.091)\end{array}$ & $\begin{array}{l}-0.499^{*} \\
(0.286)\end{array}$ \\
\hline default & $\begin{array}{l}-0.285^{*} \\
(0.158)\end{array}$ & $\begin{array}{l}0.379 \\
(0.352)\end{array}$ & $\begin{array}{l}-0.198 \\
(0.231)\end{array}$ & $\begin{array}{l}-0.170 \\
(0.260)\end{array}$ & $\begin{array}{l}0.013 \\
(0.132)\end{array}$ & $\begin{array}{l}-0.412 \\
(0.353)\end{array}$ & $\begin{array}{l}-0.206^{* * *} \\
(0.071)\end{array}$ & $\begin{array}{l}0.033 \\
(0.227)\end{array}$ \\
\hline Constant & $\begin{array}{l}0.301 \\
(0.399)\end{array}$ & $\begin{array}{l}1.477 \\
(1.562)\end{array}$ & $\begin{array}{l}1.339 \\
(0.839)\end{array}$ & $\begin{array}{l}2.219 * * * \\
(0.475)\end{array}$ & $\begin{array}{l}0.449 * * \\
(0.217)\end{array}$ & $\begin{array}{l}3.385^{* * *} \\
(0.866)\end{array}$ & $\begin{array}{l}0.365 \\
(0.228)\end{array}$ & $\begin{array}{l}2.425^{* * *} \\
(0.900)\end{array}$ \\
\hline Observations & 2241 & 1130 & 2702 & 2845 & 1187 & 2851 & 2872 & 2688 \\
\hline R-squared & 0.11 & 0.12 & 0.12 & 0.31 & 0.16 & 0.25 & 0.19 & 0.39 \\
\hline
\end{tabular}


Table 8a: High-income economies (based on a log linear trend)

\begin{tabular}{|c|c|c|c|c|c|c|c|c|}
\hline & (1) & (2) & (3) & (4) & (5) & (6) & (7) & $(8)$ \\
\hline & \multicolumn{8}{|l|}{ Sovereign } \\
\hline & Banks & Bonds & $\begin{array}{l}\text { Private } \\
\text { creditors }\end{array}$ & Official & IMF & Total & $\begin{array}{l}\text { Total } \\
\text { private }\end{array}$ & FDI \\
\hline \multirow[t]{2}{*}{ output gap } & $1.223 * * *$ & -0.082 & $0.956^{* *}$ & -0.018 & $-0.719 *$ & 0.626 & $0.464 * * *$ & 2.865 \\
\hline & $(0.392)$ & $(0.406)$ & $(0.416)$ & $(0.751)$ & $(0.423)$ & $(0.922)$ & $(0.138)$ & $(2.346)$ \\
\hline \multirow[t]{2}{*}{ past default } & $-0.387 * *$ & -0.038 & $-0.793 * * *$ & -0.163 & -0.137 & $-1.027 * *$ & 0.041 & $-0.749 * *$ \\
\hline & $(0.195)$ & $(0.106)$ & $(0.256)$ & $(0.317)$ & $(0.157)$ & $(0.430)$ & $(0.095)$ & $(0.320)$ \\
\hline \multirow[t]{2}{*}{ default } & -0.115 & 0.046 & -0.043 & 0.041 & 0.200 & -0.053 & $-0.269 * * *$ & -0.072 \\
\hline & $(0.185)$ & $(0.087)$ & $(0.188)$ & $(0.248)$ & $(0.137)$ & $(0.318)$ & $(0.083)$ & $(0.226)$ \\
\hline \multirow[t]{2}{*}{ Constant } & $0.286 * * *$ & -0.056 & 0.862 & $1.757 * * *$ & -0.120 & $2.575 * * *$ & $0.274 * * *$ & 1.030 \\
\hline & $(0.105)$ & $(0.129)$ & $(0.640)$ & $(0.421)$ & $(0.188)$ & $(0.715)$ & $(0.068)$ & $(0.760)$ \\
\hline Observations & 1523 & 807 & 1852 & 1911 & 786 & 1916 & 1935 & 1865 \\
\hline R-squared & 0.15 & 0.32 & 0.16 & 0.42 & 0.15 & 0.35 & 0.27 & 0.39 \\
\hline
\end{tabular}

Robust standard errors in parentheses

* significant at 10\%; ** significant at 5\%; *** significant at $1 \%$

57 countries.

Table 8b: Low-income economies (based on a log linear trend)

\begin{tabular}{|c|c|c|c|c|c|c|c|c|}
\hline & (1) & (2) & (3) & (4) & (5) & (6) & (7) & $(8)$ \\
\hline & \multicolumn{8}{|l|}{ Sovereign } \\
\hline & Banks & Bonds & $\begin{array}{l}\text { Private } \\
\text { creditors }\end{array}$ & Official & IMF & Total & Total private & FDI \\
\hline output gap & $\begin{array}{l}0.730 \\
(0.446)\end{array}$ & $\begin{array}{l}0.795 \\
(0.605)\end{array}$ & $\begin{array}{l}0.809 \\
(0.608)\end{array}$ & $\begin{array}{l}-7.132 * * * \\
(1.933)\end{array}$ & $\begin{array}{l}-2.251^{* *} \\
(1.059)\end{array}$ & $\begin{array}{l}-6.228 * * * \\
(2.069)\end{array}$ & $\begin{array}{l}0.369 \\
(0.297)\end{array}$ & $\begin{array}{l}4.300 * * * \\
(0.994)\end{array}$ \\
\hline past default & $\begin{array}{l}-0.555^{* * *} \\
(0.186)\end{array}$ & $\begin{array}{l}-0.068 \\
(0.187)\end{array}$ & $\begin{array}{l}-1.128 * * * \\
(0.252)\end{array}$ & $\begin{array}{l}0.347 \\
(0.329)\end{array}$ & $\begin{array}{l}-1.952 \\
(1.235)\end{array}$ & $\begin{array}{l}-0.858 * * \\
(0.404)\end{array}$ & $\begin{array}{l}0.395 * * * \\
(0.143)\end{array}$ & $\begin{array}{l}0.270 \\
(0.289)\end{array}$ \\
\hline default & $\begin{array}{l}-0.626^{* * *} \\
(0.150)\end{array}$ & $\begin{array}{l}0.140 \\
(0.368)\end{array}$ & $\begin{array}{l}-0.715^{* *} \\
(0.320)\end{array}$ & $\begin{array}{l}-0.556^{*} \\
(0.287)\end{array}$ & $\begin{array}{l}-0.097 \\
(0.230)\end{array}$ & $\begin{array}{l}-1.294 * * * \\
(0.430)\end{array}$ & $\begin{array}{l}-0.389^{* * *} \\
(0.104)\end{array}$ & $\begin{array}{l}-0.008 \\
(0.278)\end{array}$ \\
\hline Constant & $\begin{array}{l}0.179 \\
(0.443)\end{array}$ & $\begin{array}{l}1.531 \\
(1.497)\end{array}$ & $\begin{array}{l}1.301 \\
(1.041)\end{array}$ & $\begin{array}{l}1.834 * * * \\
(0.597)\end{array}$ & $\begin{array}{l}1.690 * \\
(0.995)\end{array}$ & $\begin{array}{l}2.955 * * * \\
(1.098)\end{array}$ & $\begin{array}{l}0.458 \\
(0.354)\end{array}$ & $\begin{array}{l}3.498 * * * \\
(0.992)\end{array}$ \\
\hline Observations & 1652 & 1193 & 1810 & 1889 & 803 & 1895 & 1897 & 1795 \\
\hline R-squared & 0.17 & 0.12 & 0.16 & 0.28 & 0.20 & 0.24 & 0.13 & 0.42 \\
\hline
\end{tabular}

Robust standard errors in parentheses

$*$ significant at $10 \%$; $*$ significant at $5 \%$; *** significant at $1 \%$ 63 countries. 
Table 9: The leverage factor.

(based on a log linear trend)

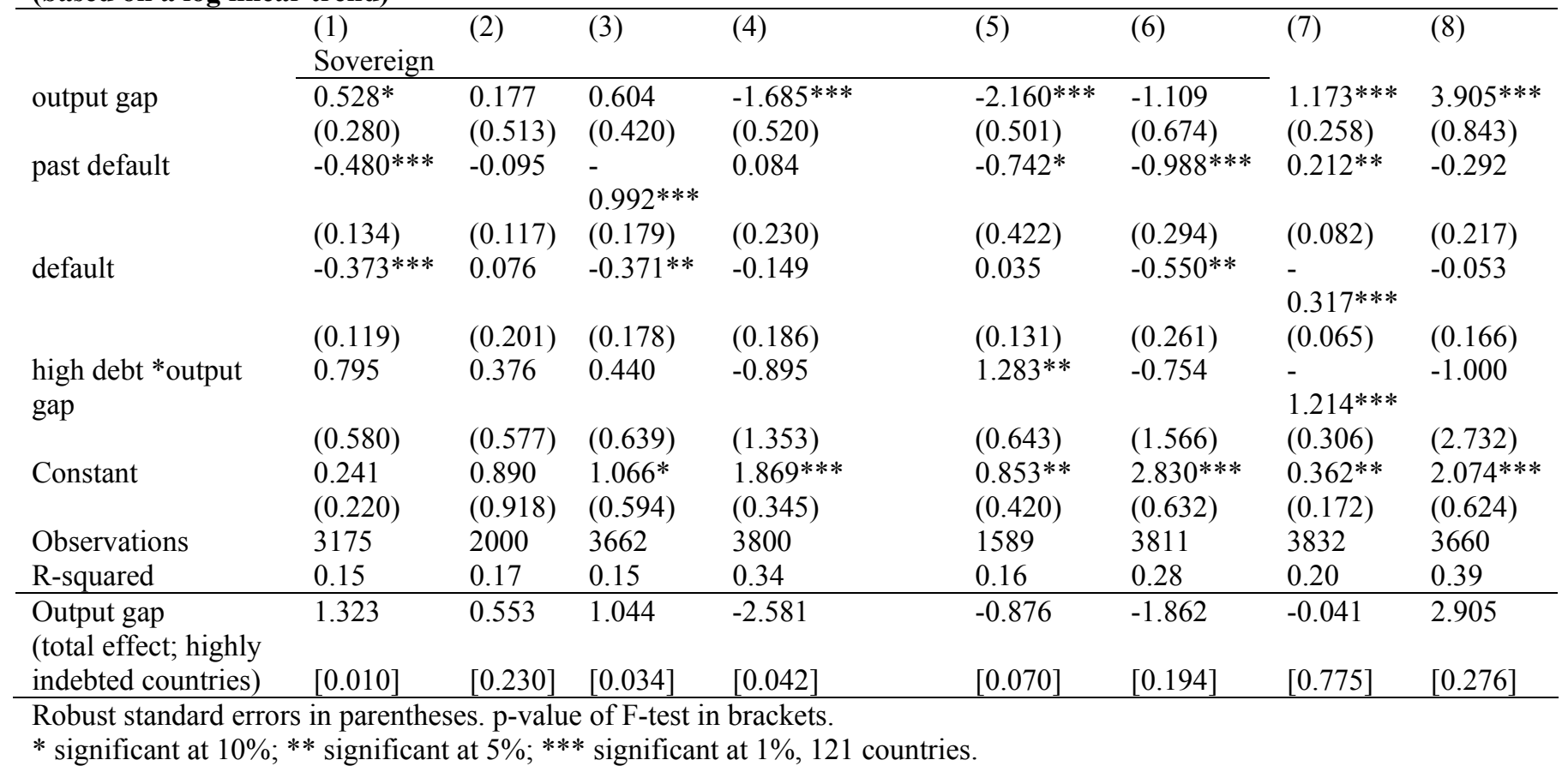


Table 10: Complements or Subtitutes? (based on a log linear trend)

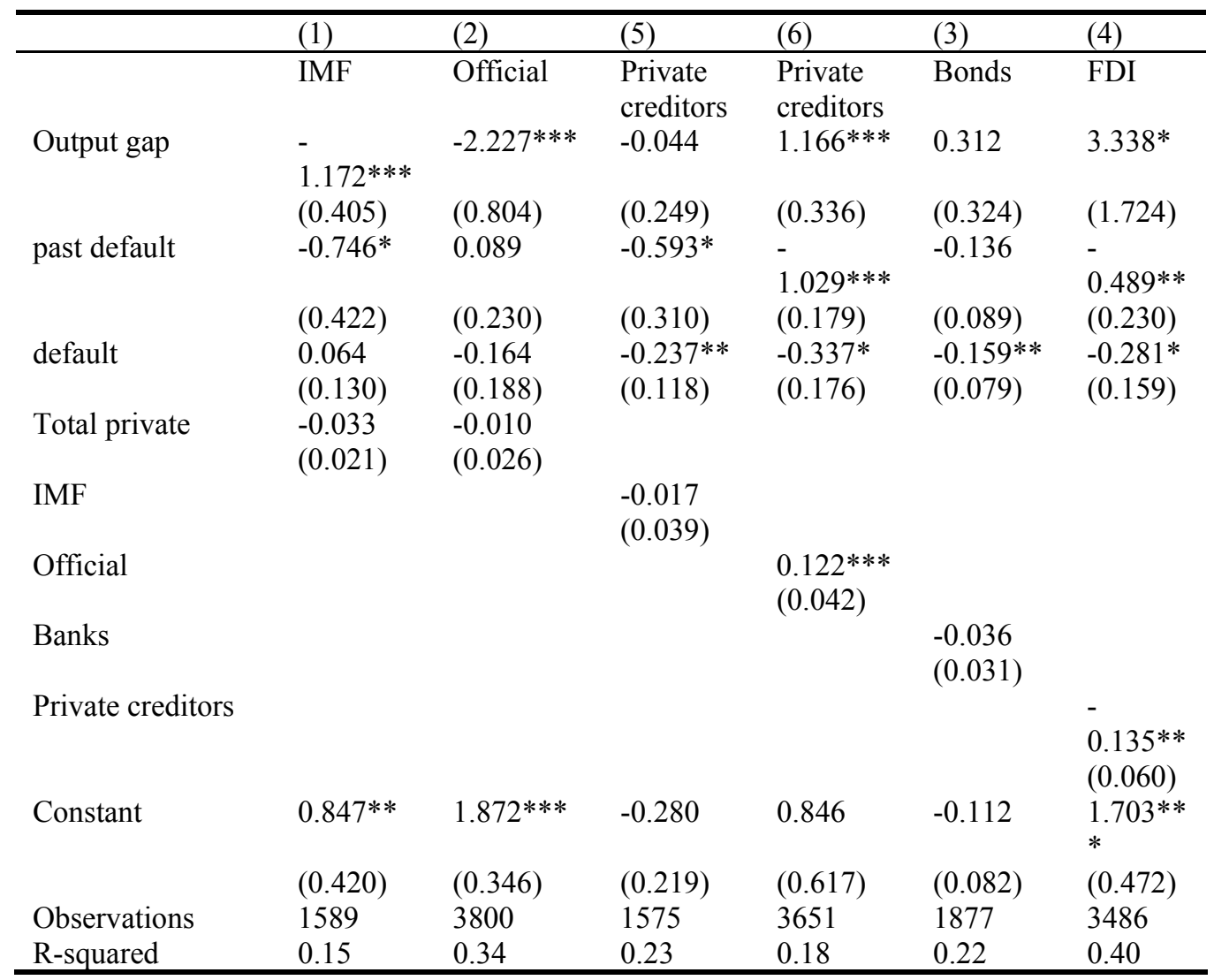

Robust standard errors in parentheses

* significant at $10 \%$;* significant at $5 \%$; ** significant at $1 \%$

113 countries. 
Figure 1:

Defaults and Debt Flows

(2000-2004 average, \% of current GDP)

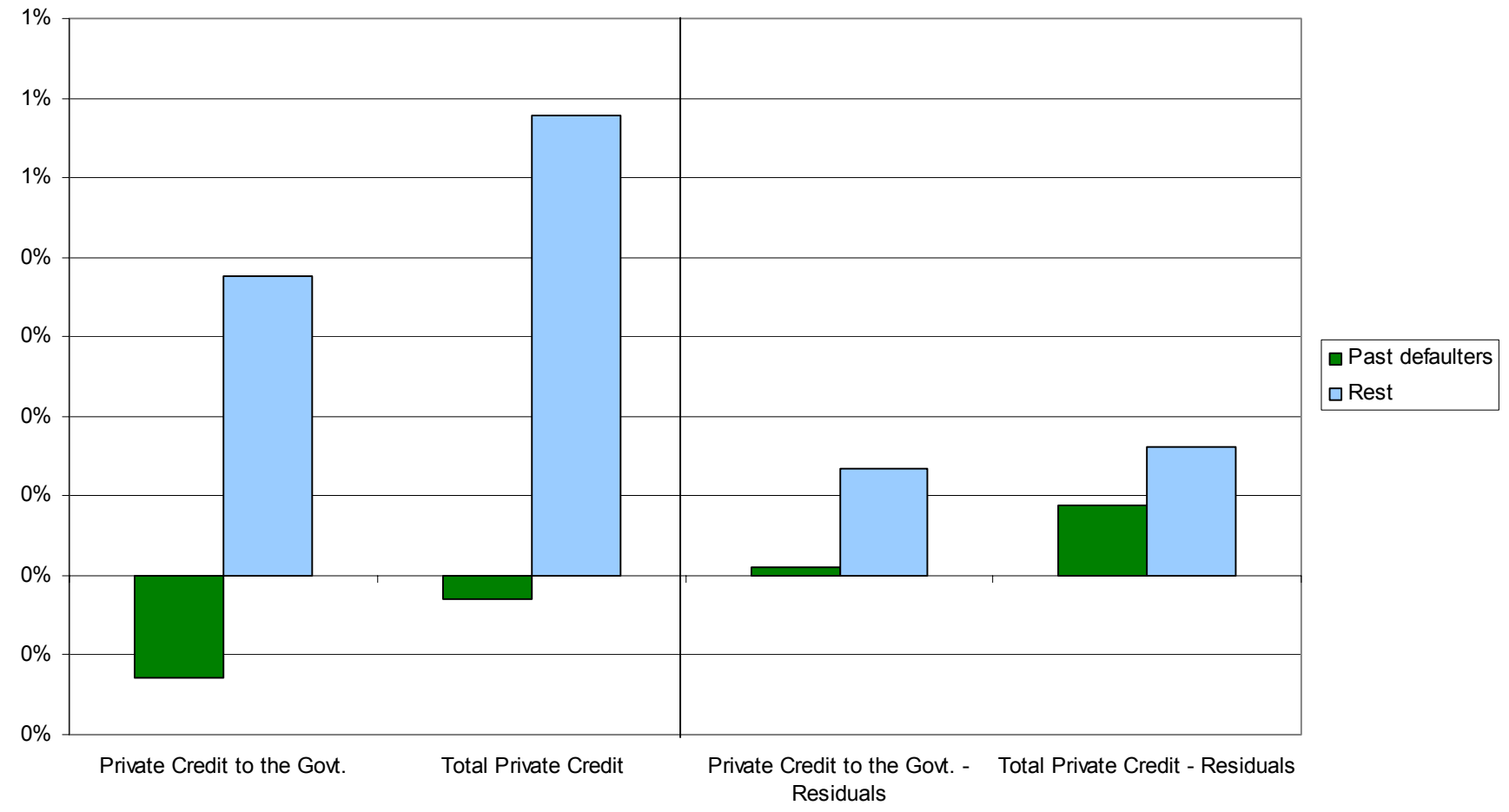

